\title{
Kajian Numerik terhadap Perilaku Seismik Link Panjang dengan Pemasangan Pengaku Diagonal Badan pada Sistem Struktur Rangka Baja Tahan Gempa Tipe Eccentrically Brace Frames (EBF)
}

\author{
Yurisman ${ }^{1)}$, Bambang Budiono'), Nidiasari3 ${ }^{3)}$, Merley Misriani ${ }^{4)}$, Enita Suardi ${ }^{5}$ \\ 1),4,5) Politeknik Negeri Padang, Kampus Unand Limau Manis \\ 2)FTSL ITB \\ 3) Universitas Andalas, Kampus Unand Limau Manis \\ Email :yurisman pdg@yahoo.com.
}

\begin{abstract}
:
This paper presents a numerical study to investigate the behaviour of Llink in case of enhancement of the long link performance of Eccentrically Braced Frames (EBF) of steel structures by using diagonal web stiffenner. This research aims to investigate the behaviour of long link with diagonal stiffenner under monotonic and cyclic of loading with displacement control, the loading hystory is applied to the model of link accordance with standard of AISC 2010. Non-Linier Finite Element Method is applied using the computer software of MSC/NASTRAN. Link is modeled as shell element of CQUAD of MSC/NASTRAN and fixed at its both ends except for degree of freedom of the vertical displacement ( $y$-direction) at the one end where the load is applied. The link length is $1555 \mathrm{~mm}$ and the section of link is WF 150.75. The behaviour of long link with diagonal web stiffener is compared to the behaviour of the link designed in accordance with the AISC 2010 Standard Code of Practice. The results of the analysis show that the diagonal web stiffenerincreases the performance of the long link in terms of strength, stiffness, energy dissipation to resist lateral load. However, the difference between characteristic of the long link with diagonal web stiffenner and standard link of AISC Code is not significant.
\end{abstract}

Key words : long link, diagonal web stiffener, strength, stiffness, energy of dissipations.

\begin{abstract}
Abstrak
Makalah ini merupakan hasil studi numerik yang meneliti perilaku seismik terhadap link panjang dengan menggunakan pengaku diagonal pada bagian badan untuk meningkatkan kinerjanya, pada sistem struktur baja berpengaku eksentrik (EBF). Perilaku seismik ini mencakup kekuatan (strength), kekakuan (stiffeness), daktilitas (ductility) dan dissipasi energi (energy of dissipation). Penelitian ini bertujuan untuk meneliti perilaku link panjang dengan menggunakan pengaku diagonal pada bagian badan dibawah pembebanan statik monotonik dan siklik dengan kontrol perpindahan (displacement control), riwayat pembebanan yang diberikan dalam pengujian ini sesuai dengan standar pembebanan AISC 2010. Analisis dilakukan dengan pendekatan elemen hingga NonLinier dengan menggunakan perangkat lunak komputer MSC/NASTRAN. Link dimodelkan sebagai elemen shell CQUAD yang ditumpu pada kedua ujungnya sedangkan beberapa nodal pada posisi pembebanan diperbolehkan untuk bertranslasi dalam satu arah saja (arah sumbu-y). Panjang link yang digunakan dalam analisa ini adalah $1555 \mathrm{~mm}$ penampang link profil WF 150.75. Perilaku link panjang dengan pengaku diagonal badan dibandingkan dengan perilaku link panjang standard yang direncanakan sesuai dengan ketentuan AISC 2010. Hasil analisis menunjukkan bahwa pengaku diagonal badan dapat meningkatkan kinerja link panjang dalam hal : kekuatan kekakuan dan dissipasi energi dalam menahan beban lateral. Namun, perbedaan perilaku antara link panjang dengan pengaku diagonal badan dan link panjang yang direncanakan sesuai standar AISC tidak begitu signifikan.
\end{abstract}

Kata Kunci : link panjang, pengaku diagonal badan, kekuatan, kekakuan, dissipasi energi. 


\section{PENDAHULUAN}

\subsection{Latar Belakang}

Baja merupakan alternatif bangunan tahan gempa yang sangat baik. Jika dibandingkan dengan struktur beton, baja dinilai memiliki sifat daktilitas yang dapat dimanfaatkan pada saat struktur memikul beban akibat gempa. Desain sistem portal baja untuk bangunan tahan gempa yang telah dikembangkan yaitu Moment-Resisting Frames (MRF), Concentrically Braced Frames (CBF) serta Eccentrically Braced Frames(EBF).

Desain struktur rangka baja dengan konsep Momen Resisting Frames(MRF) memiliki kapasitas energy disipasi cukup baik terhadap kebutuhan daktilitas struktur, namun penggunaan konsep ini mengharuskan penggunaan elemen struktur yang besar dan mahal agar persyaratan drift pada struktur dapat dipenuhi. Pada sistem Concentrically Braced Frames (CBF), batasan drift dapat dipenuhi dengan lebih mudah namun tidak memberikan mekanisme yang stabil untuk memberikan energi disipasi yang baik. Karena keterbatasan pada kedua system tersebut, maka berkembang sistem ketiga yaitu Eccentrically Braced Frames (EBF).

Penelitian tentang link yang banyak dilakukan sampai saat ini baik secara eksperimental maupun analitis didominasi oleh link geser. Hal ini disebabkan karena link geser memperlihatkan perilaku yang baik dalam hal kekakuan, kekuatan dan energi disipasi.Sehingga dalam desain lebih direkomendasikan penggunaan link geser pada Eccentrically Braced Frames (EBF).Namun deformasi pada link pendek ditandai dengan sudut deformasi yang besar yang erat kaitannya dengan drift yang terjadi pada struktur dan berpotensi menyebabkan kerusakan terhadap elemen-elemen nonstruktural. Pada sisi lain, link panjang terbukti mempunyai sudut deformasi yang lebih kecil dari link pendek, tetapi mempunyai tingkat daktilitas yang lebih rendah. Dilihat dari segi arsitektural pemasangan link yang lebih panjang akan memberikan ruang yang lebih luas untuk dimanfaatkan sebagai area bukaan seperti pintu dan jendela.

\subsection{Maksud dan Tujuan}

Sesuai dengan pernyataan yang telah dikemukakan dalam latar belakang masalah, penelitian ini bertujuan untuk mendapatkan suatu sistem struktur baja berpengaku eksentrik (EBF) yang mempunyai kinerja maksimal melalui peningkatan kinerja link panjang (long link) dengan memasang pengaku diagonal pada badan elemen link tersebut.Diharapkan dengan melakukan inovasi ini maka dapat dilakukan kajian terhadap penggunaan pengaku badan yang dipasang secara diagonal pada elemen link, dalam rangka peningkatan kinerja link dalam sistem EBF.

\subsection{Studi Literatur}

\subsubsection{Struktur rangka baja berpenopang eksentrik (Eccentrically Braced Frame)}

Eccentrically Braced Frames (EBF) merupakan konsep desain gabungan antara konsep daktilitas dan disipasi energi yang baik dari desain Moment-Resisting Frames (MRF) dengan karakteristik kekakuan elastik yang tinggi dari desain Concentrically Braced Frames (CBF). Karakteristik yang membedakan EBF dengan desain struktur tahan gempa MRF dan CBF adalah adanya 
penghubung yang terdapat pada setidaknya salah satu ujung dari bracing yang disebut sebagai link (Gambar 1). Konsep desain tahan gempa EBF adalah elemen link ditetapkan sebagai bagian yang akan rusak sedangkan elemen lain diharapkan tetap berada dalam kondisi elastik. Kelehan yang terjadi pada elemen link dapat berupa kelelehan geser atau kelelehan lentur. Tipe kelelehan ini sangat tergantung pada panjang link tersebut. (Engelhardt dan Popov ,1989;1992).

sama . Deformasi yang dihasilkan berbentuk S dengan titik balik pada tengah bentang dan besarnya momen yang bekerja adalah sebesar 0.5 kali besar gaya geser dikali dengan panjang link. Plastifikasi yang terjadi pada suatu elemen link disebabkan karena kedua gaya tersebut. Gambaran gaya yang bekerja pada elemen link diperlihatkan pada Gambar

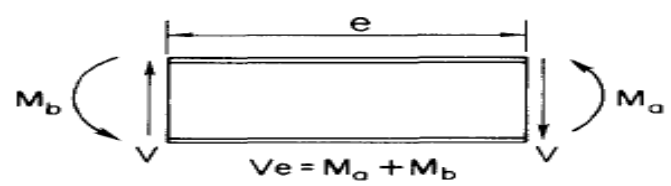

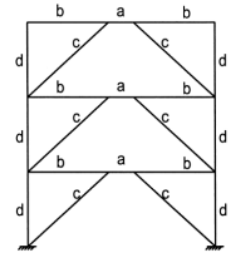

(a)

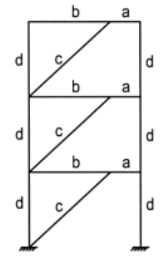

(b)

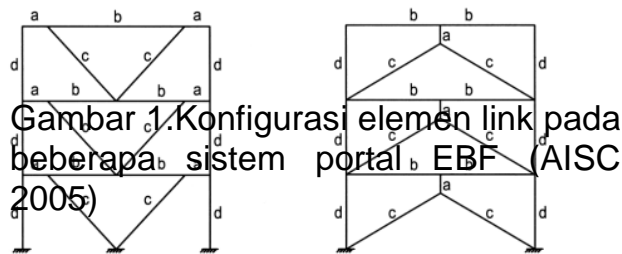

(d)

(c)

$a=\operatorname{Lin}$

$b=$ beam segment outside of Link

$\mathrm{c}=$ diagonal brace

$\mathrm{d}=$ column

Link berperan sebagai ductile fuse, mendisipasi energi sepanjang perilaku histerisis yang stabil dan membatasi gaya terhadap brace, kolom dan balok diluar link. Link berperilaku sebagai balok pendek dengan gaya geser yang bekerja berlawanan arah pada kedua ujungnya. Karena adanya gaya geser yang bekerja pada kedua ujung balok, maka momen yang dihasilkan pada kedua ujung balok mempunyai besar dan arah yang
2.

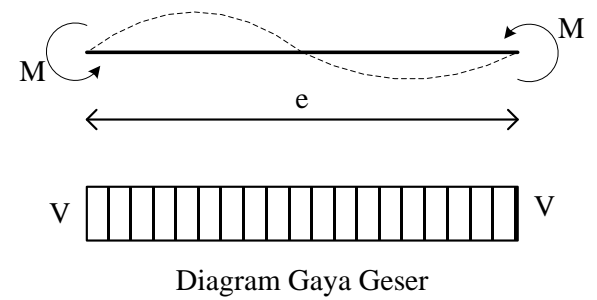

.

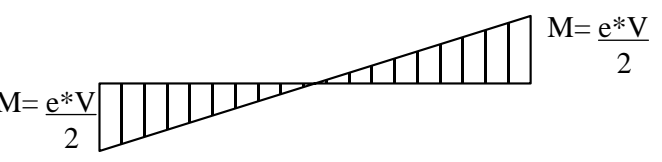

Diagram Momen

Gambar 2.Gaya yang bekerja pada link(Engelhart dan Popov,1988; Becker dan M. Isler, 1996)

Sesuai dengan fungsinya sebagai sekering (fuse) yang mendisipasikan energi lewat mekanisme sendi plastik (fully plastic hinge mechanism) maka link tidak boleh mengalami tekuk elastik dan tekuk inelastik (partially plastic buckling) sebelum kapasitas rotasi sendi plastik yang disyaratkan dalam peraturan tercapai. Oleh karena itu dalam pemilihan penampang link yang akan dipakai sesuai dengan modulus elastisitas (E) dan mutu baja yang dipakai $\left(f_{y}\right)$ telah ditetapkan batasan kelangsingan yang harus dipenuhi sesuai dengan peraturan yang berlaku. Setelah terpenuhinya syarat kelangsingan 
suatu profil link yang dipilih dalam disain maka tahapan selanjutnya yang harus di perhitungkan adalah syarat panjang tekuk elastik dan inelastik dari link.

Pengecekan kapasitas geser plastis pada link dilakukan sesuai dengan rumus (1) dan (2) :

$V_{p}=0.6 \cdot F_{y} \cdot A_{w}$

$A_{w}=t_{w} \cdot\left(h-2 \cdot t_{f}\right)=t_{w} \cdot h_{w}$

dimana :

$$
\begin{aligned}
A_{w} & =\text { Luas efektif pelat badan } \\
t_{w} & =\text { Tebal pelat badan } \\
t_{f} & =\text { Tebal pelat sayap } \\
h & =\text { Tinggi profil }
\end{aligned}
$$

Perumusan diatas berlaku langsung apabila nilai efek dari gaya aksial berfaktor $\left(\mathrm{P}_{\mathrm{u}}\right)$ yang terjadi pada elemen link dalam kondisi $\mathrm{P}_{\mathrm{u}} \leq$ $0.15 P_{y}$, sedangkan apabila kondisi yang terpenuhi adalah $\mathrm{P}_{\mathrm{u}}>\quad 0.15 \quad \mathrm{P}_{\mathrm{y}}$ maka persyaratan tambahan yang harus dipenuhi sesuai dengan ketentuan pada peraturan yang berlaku.

Tahapan selanjutnya adalah penentuan apakah link termasuk jenis link geser atau link lentur berdasarkan perbandingan antara momen plastis $\left(M_{p}\right)$ dengan geser plastis $\left(V_{p}\right)$. Momen plastis $\left(\mathrm{M}_{\mathrm{p}}\right)$ yang dirumuskan sebagai berikut :

$M_{p}=F_{y} \cdot Z$

dimana :

$$
\begin{aligned}
& F_{y}=\text { Tegangan leleh baja } \\
& Z \quad=\text { Modulus tahanan plastis } \\
& \text { penampang. }
\end{aligned}
$$

$\begin{array}{lrrr}\text { Panjang link } & \text { yang } & \text { disyaratkan } & (\text { eall } \\ \text { disesuaikan } & \text { dengan } & \text { klasifikasi } & \text { link }\end{array}$

berdasarkan perbedaan panjang berdasarkan AISC, Seismic Provisions for Structual Steel Buildings . Mekanisme kelelehan link, kapasitas energi disipasi dan mode kegagalan sangat erat hubungannya dengan faktor panjang dari link. Untuk link pendek, perilaku inelastik dominan terhadap gaya geser, sebaliknya untuk link panjang perilaku inelastik didominasi oleh lentur. Untuk link art\&ara (intermediate link), kelelehan dipengaruhi oleh geser dan lentur

Semakin pendek link, maka semakin besar pengaruh gaya geser terhadap perilaku inelastik. Kelelehan geser terjadi seragam sepanjang link.Untuk link yang sangat pendek gaya geser link mencapai kapasitas geser plastis $\mathrm{Vp}=0.6 . \mathrm{d}$.tw.Fy, sebelum momen ujung mencapai momen plastis $\mathrm{Mp}=\mathrm{Zx}$.Fy, dan link leleh akibat geser membentuk sebuah sendi geser. Link geser mempunyai sifat sangat daktil dengan kapasitas inelastik yang melebihi kapasitas geser badan, sehingga kegagalan buckling tejadi pada web. (Yurisman,dkk, 2010)

Untuk link yang lebih panjang, momen ujung mencapai $\mathrm{Mp}$ membentuk sendi-sendi lentur sebelum terjadinya kelelehan geser. Mekanisme keruntuhan yang terjadi pada link panjang disebabkan karena deformasi lentur yang menyebabkan terjadinya kegagalan yand 3 ) merupakan kombinasi dari terjadinya buckling pada sayap (flens), compression buckling pada badan (web) dan/atau lateral torsional buckling. Sebagai tambahan, akibat regangan yang sangat besar pada kedua ujung link maka besar kemungkinan terjadinya fracture pada sambungan las ujung pada saat terjadi mode keruntuhan batas (the ultimate failure mode). 
Klasifikasi link berdasarkan perbedaan panjang berdasarkan AISC, Seismic

Provisions for Structual Steel Buildings adalah sebagai berikut : (AISC, 2005)

a. Link geser murni, e $\leq 1.6 \mathrm{Mp} / \mathrm{V}_{\mathrm{p}}$ Kelelehan pada link jenis ini didominasi oleh geser.

b. Link dominan geser, $1.6 \mathrm{Mp} / \mathrm{V}_{\mathrm{p}} \leq \mathrm{e} \leq 2.6$ $\mathrm{Mp} / \mathrm{V}_{\mathrm{p}}$

Kelelehan pada link jenis ini merupakan kombinasi antara geser dan lentur

C. Link dominan lentur 2.6 $\mathrm{Mp}_{\mathrm{p}} / \mathrm{V}_{\mathrm{p}}<\mathrm{e} \leq 5$ $\mathrm{Mp} / \mathrm{V}_{\mathrm{p}}$

Kelelehan pada link jenis ini merupakan kombinasi antara geser dan lentur

d. Link lentur murni e $\geq 5 \mathrm{Mp} / \mathrm{V}_{\mathrm{p}}$

Kelelehan pada link jenis ini didominasi oleh lentur

\subsubsection{Hubungan pengaku badan (web} stiffner) dan sudut rotasi terhadap kinerja link

Pengaku setinggi badan penuh diperlukan pada sisi-sisi ujung link agar bisa mentransfer gaya geser sebaik mungkin tanpa terjadi tekuk badan. Untuk link yang berperilaku sebagai link geser/pendek, jarak maksimum pengaku badan bagian tengah sangat tergantung pada besaran sudut rotasi link, semakin besar sudut rotasi link maka akan semakin rapat pengakunya. Pengaku badan bagian tengah pada link geser ini berfungsi untuk memperlambat terjadinya tekuk geser inelastik pada badan. Sedangkan untuk link yang berperilaku sebagai link lentur/panjang, pengaku badan bagian tengah berfungsi untuk membatasi penurunan kekuatan yang disebabkan tekuk lokal pelat sayap (flange local buckling) dan tekuk lateral torsi.
AISC 2005 mendefinisikan sudut rotasi link (link rotation angle) adalah sudut inelastik diantara link dan balok diluar link ketika total drift (simpangan) tingkat sama dengan simpangan tingkat disain. Sudut rotasi link tidak boleh melebihi nilai-nilai berikut :

a) 0,08 radian untuk link yang panjangnya $1,6 \mathrm{Mp} / \mathrm{Vp}$ atau kurang.

b) 0,02 radian untuk link yang panjangnya $2,6 \mathrm{Mp} / \mathrm{Vp}$ atau lebih.

c) Untuk link yang panjangnya antara $1,6 \mathrm{Mp} / \mathrm{Vp}$ dan 2,6Mp/Vp ditentukan dengan cara interpolasi linier.

Tabel 1. Klasifikasi jarak pengaku badan antara (intermediate stiffener)

\begin{tabular}{c|c|c|c|l}
\hline $\begin{array}{c}\text { N } \\
0\end{array}$ & Panjang Link & $\begin{array}{c}\text { Jenis } \\
\text { Link }\end{array}$ & $\begin{array}{c}\text { Rota } \\
\text { si }\end{array}$ & $\begin{array}{l}\text { Jarak } \\
\text { Pengaku } \\
\text { Maximu } \\
\text { m }\end{array}$ \\
\hline 1 & $e \leq 1.6 \frac{M_{P}}{V_{P}}$ & $\begin{array}{l}\text { Geser } \\
\text { murni }\end{array}$ & 0.08 & $30 . \mathrm{t}_{\mathrm{w}}-\mathrm{d} / 5$ \\
\cline { 4 - 5 } 2 & $1.6 \frac{M_{P}}{V_{P}}<e \leq 2.6 \frac{M_{\text {Domin }}}{V_{P}^{\text {Dn }}}$ & & $52 . \mathrm{t}_{\mathrm{w}}-\mathrm{d} / 5$ \\
\hline 3 & $2.6 \frac{M_{P}}{V_{P}}<e \leq 5 \frac{M_{P}}{V_{P}}$ & $\begin{array}{l}\text { Domin } \\
\text { an } \\
\text { lentur }\end{array}$ & 0.02 & $\begin{array}{l}1.5 \\
\text { dari dan 3 } \\
\text { dipenuhi } \\
\text { ujung link }\end{array}$ \\
\hline 4 & $e>5 \frac{M_{P}}{V_{P}}$ & $\begin{array}{l}\text { Lentur } \\
\text { murni }\end{array}$ & & $\begin{array}{l}\text { Tidak } \\
\text { memerlu } \\
\text { kan } \\
\text { pengaku } \\
\text { antara }\end{array}$ \\
\hline
\end{tabular}

\section{METODE PENELITIAN}

Penelitian ini dilakukan secara numerik dengan menggunakan paket pemograman komputer MSC/NASTRANyang lisensinya dimiliki oleh jurusan teknik mesin ITB.

Benda uji berupa profil baja WF 150.75.5.7, sebelum dilakukan pemodelan dengan elemen hingga, terlebih dahulu dilakukan pengujian di laboratorium untuk mengetahui properti material yang digunakan. 


\subsection{Pengujian di Laboratorium}

Pengujian material dilakukan dengan langkah langkah sebagai berikut :

1. Pembuatan benda uj.

2. Pemasangan strain gage (alat ukur regangan).

3. Pengujian.

4. Hasil pengujian berupa kurva tegangan vs regangan.

Gambar 3 menunjukkan proses pengujian dengan menggunakan mesin UTM..
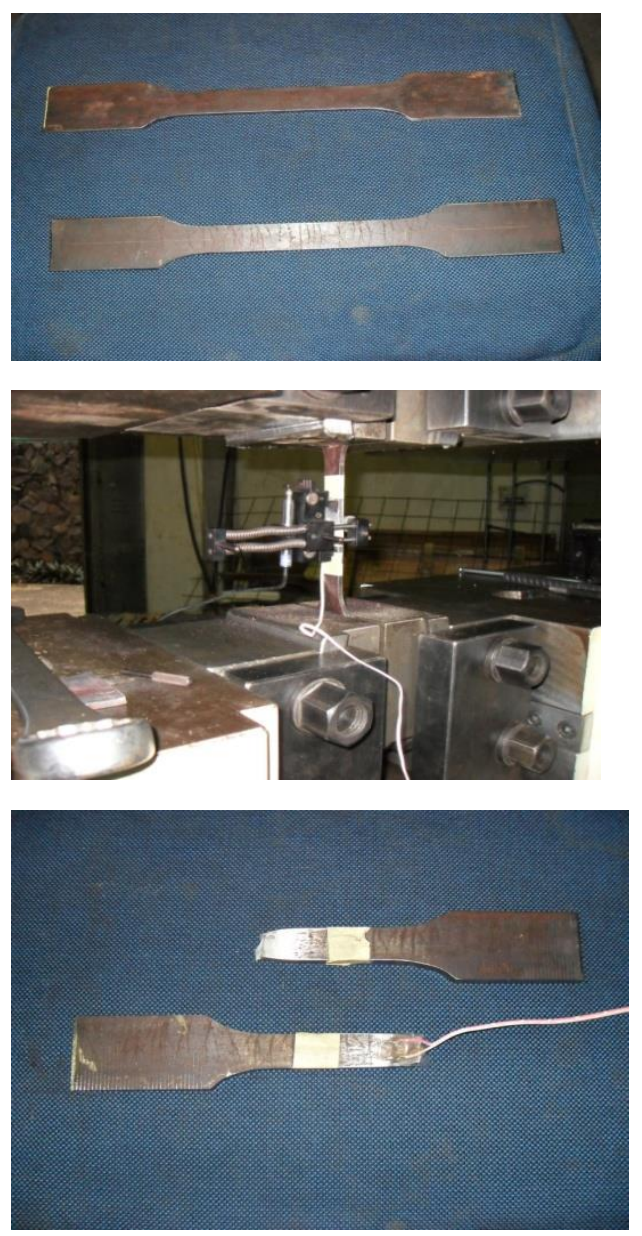

Gambar 3.Uji tarik baja (coupon test) di laboratorium mekanika struktur ITB.
Gambar 4 menunjukkan hasil pengujian berupa kurva tegangan vs regangan untuk bagian sayap dan badan dari profil baja WF 150.75.5.7.
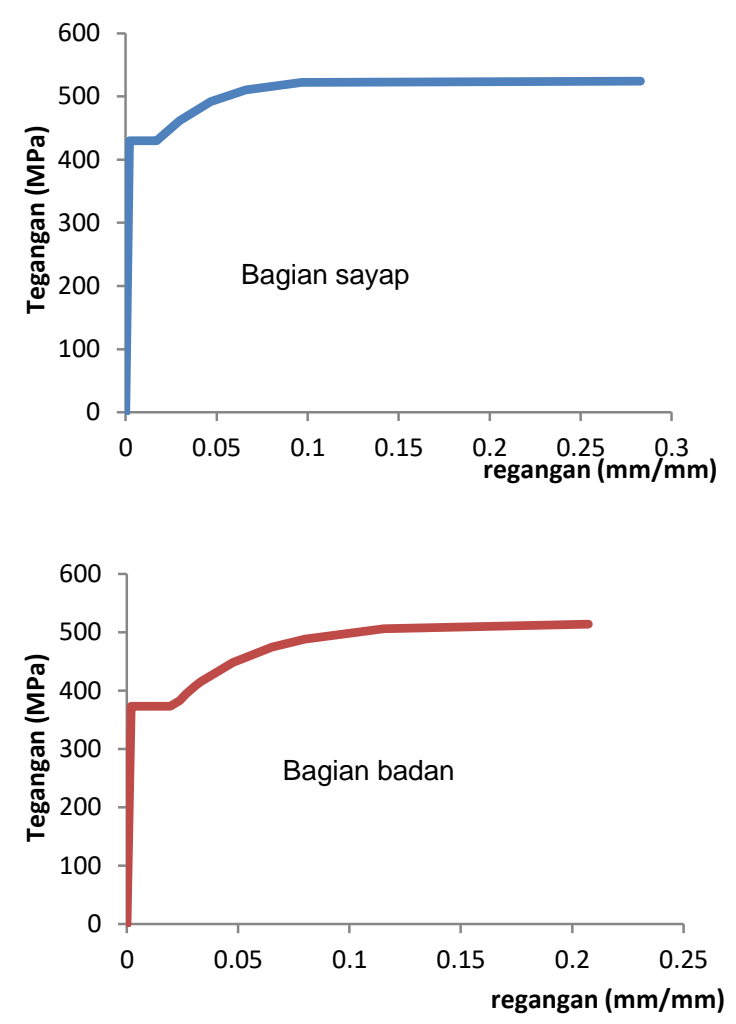

Gambar 4.Kurva tegangan vs regangan hasil uji tarik..

\subsection{Kajian secara Numerik}

\subsubsection{Pemodelan elemen Link}

Elemen Link pada rangka baja berpengaku eksentrik pada dasarnya adalah merupakan balok yang menahan momen, gaya geser atau gaya aksial. Untuk mempelajari perilaku elemen tersebut dilakukan pemisahan dari rangka induknya (subassembly) dan dalam analisanya dianggap sebagai balok tunggal. Pada kajian awal ini elemen link dimodelkan sebagai balok yang dijepit pada kedua ujungnya dan diberi perpindahan transversal pada salah satu ujungnya. Hal ini menyebabkan link pada sisi yang diberi beban 
transversal memiliki lima derajat kebebasan sedang sisi lainnya terjepit sempurna dan memiliki enam derajat kebebasan sehingga gaya yang bekerja seperti pada Gambar 2 dapat didekati.

Link dimodelkan sebagai elemen shell melalui pendekatan elemen hingga dimana tiap elemen terdiri dari empat node dan tiap node mempunyai enam derajat kebebasan. Geometri yang digunakan pada model berdasarkan centerline dari profil IWF yang digunakan pada pemodelan link.Gambar 5 dan 6 memperlihatkan model geometri dan model finite element link yang digunakan dalam penelitian ini.

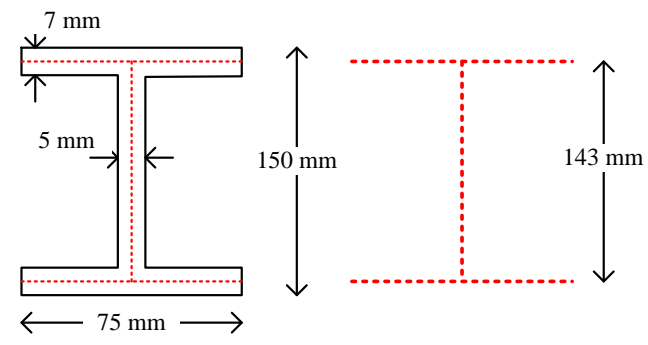

Gambar 5. Pemodelan geometri link

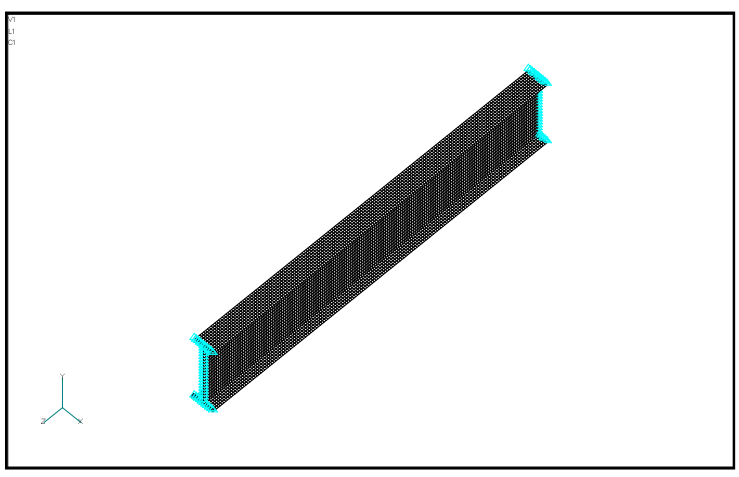

Gambar 6. Pemodelan finite element link

Profil baja yang digunakan sebagai elemen balok adalah adalah WF 150.75.5.7 dengan fungsi material baja yang digunakan adalah fungsi material yang diperoleh berdasarkan pengujian coupon di laboratorium.
Berdasarkan profil yang digunakan maka panjang elemen link yang dianalisa adalah e = $1550 \mathrm{~mm}$ dengan tipe link lentur (panjang).

Dengan menggunakan kajian numerik maka akan dilakukan analisis terhadap konfigurasi pengaku untuk mengetahui konfigurasi yang memperlihatkan perilaku link panjang yang paling baik. Berdasarkan studi tersebut maka link panjang dianalisa dengan membandingkan kinerja dan perilaku link pada tiga kondisi yaitu link tanpa pengaku badan (Gambar 7.) , link dengan pengaku diagonal badan (Gambar 8.) serta link dengan pengaku cross diagonal (Gambar 9.). Selanjutnya hasil kajian numerik ini diverifikasi dengan hasil pengujian di laboratorium.

Pembebanan yang diberikan terhadap tiga jenis benda uji adalah pembebanan static monotonik dan pembebanan siklik dengan kontrol perpindahan dengan ketentuan sebagai berikut :

(1). 6 siklus pada $\delta= \pm 5.8125 \mathrm{~mm}$

(2). 6 siklus pada $\delta= \pm 7.75 \mathrm{~mm}$

(3). 6 siklus pada $\delta= \pm 11.625 \mathrm{~mm}$

(4). 6 siklus pada $\delta= \pm 15.5 \mathrm{~mm}$

(5). 4 siklus pada $\delta= \pm 23.25 \mathrm{~mm}$

(6). 4 siklus pada $\delta= \pm 31 \mathrm{~mm}$

(7). 2 siklus pada $\delta= \pm 46.5 \mathrm{~mm}$

(8). 1 siklus pada $\delta= \pm 62 \mathrm{~mm}$

(9). 1 siklus pada Ytotal $= \pm 77.5 \mathrm{~mm}$

(10). 1 siklus pada Ytotal $= \pm 108.5 \mathrm{~mm}$

1 siklus pada Ytotal $= \pm 139.5 \mathrm{~mm}$

Pembebanan statik monotonik bertujuan untuk melihat respon benda uji dalam menahan beban statik, menentukan leleh pertama, melihat mode keruntuhan yang terjadi pada benda uji serta distribusi tegangan yang tejadi.Sedangkan pembebanan siklik bertujuan untuk mendapatkan kurva hysteretic yang 
dapat menggambarkan kemampuan disipasi energi dari benda uji.

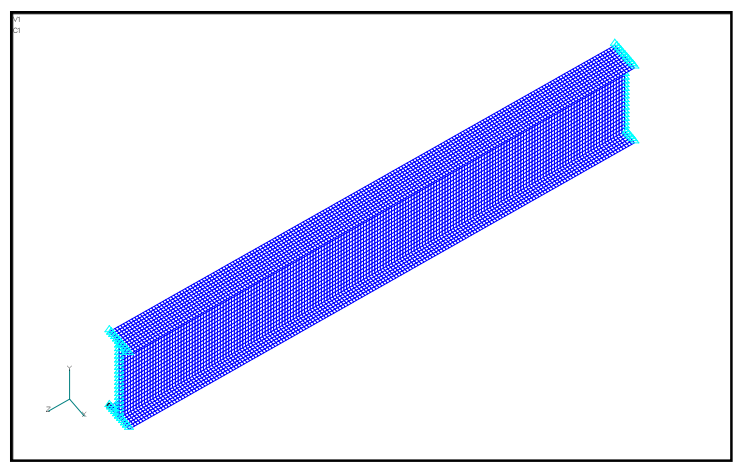

Gambar 7. Model elemen link tanpa pengaku badan

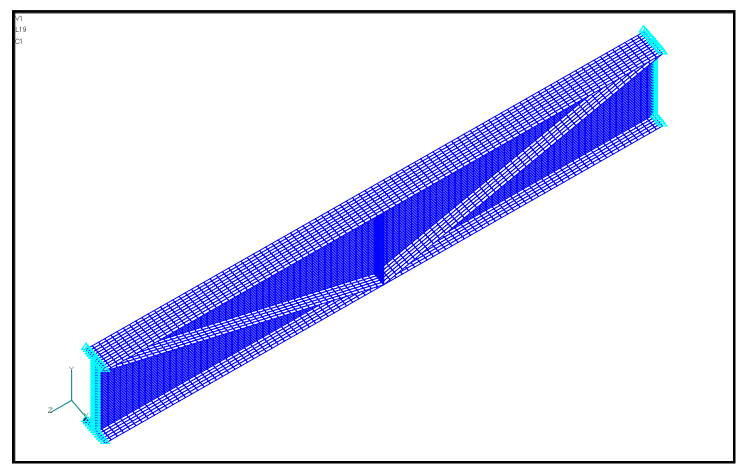

Gambar 8. Model elemen hingga link dengan pengaku diagonal badan

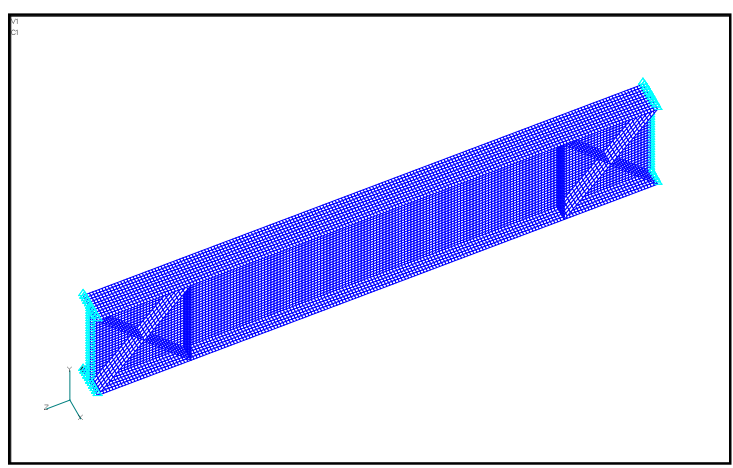

Gambar 9. Model elemen hingga link dengan pengaku cross diagonal badan

Bagan alir pada gambar 10 menunjukkan tahap - tahap yang akan dilakukan dalam pengkajian secara numerik terhadap perilaku link panjang

\section{PRE PROCESSOR}

- Pemodelan geometric link

- Pemilihan elemen

- Diskritisasi

- Pemodelan properti material

- Pembebanan statik monotonik dan siklik

- Penentuan kondisi batas<smiles>C1=CCCCC1</smiles>

\section{SOLUTION}

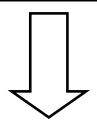

\section{POST PROCESSOR}

- Stress distribution

- Structural displacement

- Strain distribution

- Load vs displ. and load vs rotation curve

- dan lain lain sesuai kebutuhan

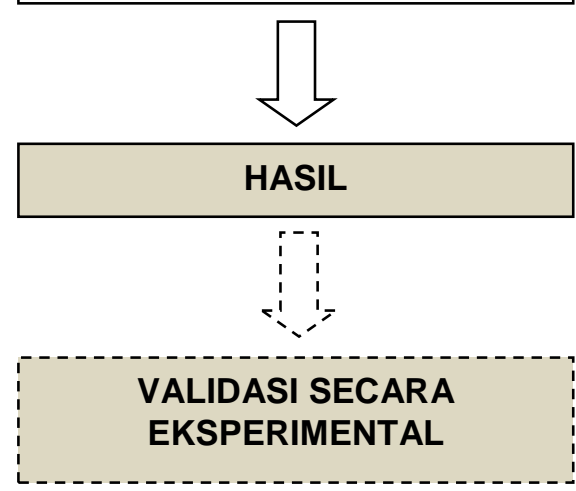

Gambar 10. Bagan alir tahap kajian numerik

\section{HASIL DAN PEMBAHASAN}

\subsection{Perilaku link panjang sesuai ketentuan AISC 2010}

Kinerja link dapat dilihat melalui kekuatan (strength), kekakuan (stiffness) , dan kemampuan link dalam mendisipasi energi. Besarnya nilai kekuatan dan kekakuan dapat 
ditinjau dari kurva beban vs perpindahan yang diperoleh dari link panjang dengan pemberian beban statik monotonik.Sedangkan kemampuan link dalam mendisipasi energi dapat diketahui dengan memberikan beban siklik pada elemen link.Pemberian beban disesuaikan dengan besarnya displacement yang dicapai oleh benda uji pada saat benda uji mencapai kekuatan maksimum sebelum mengalami keruntuhan.

Melalui analisis numerik dengan pemberian beban statik monotonik diketahui bahwa kelelehan awal terjadi pada perpindahan $\boldsymbol{\delta}_{\mathbf{y}}=$ $15.48 \mathrm{~mm}$ dengan beban pada saat leleh awal terjadi yaitu sebesar $\mathbf{P}_{\mathbf{y}}=50164.58 \mathrm{~N}$. Sedangkan kemampuan link dalam mendisipasi energi dapat dilihat pada kurva hysteresis. Bentuk kurva hysteresis yang cukup gemuk dan stabil menunjukkan bahwa link panjang tanpa pengaku badan memiliki kemampuan disipasi yang cukup baik dengan daktilitas $\mu=5.006$.

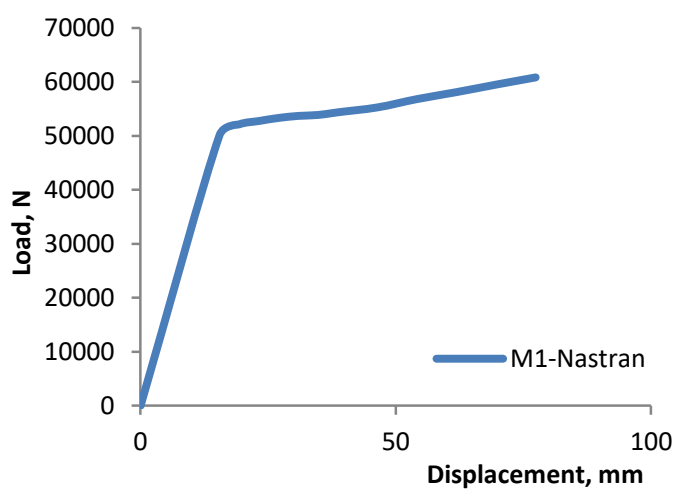

Gambar 11.Kurva beban vs perpindahan terhadap link panjang dengan beban monotonik.

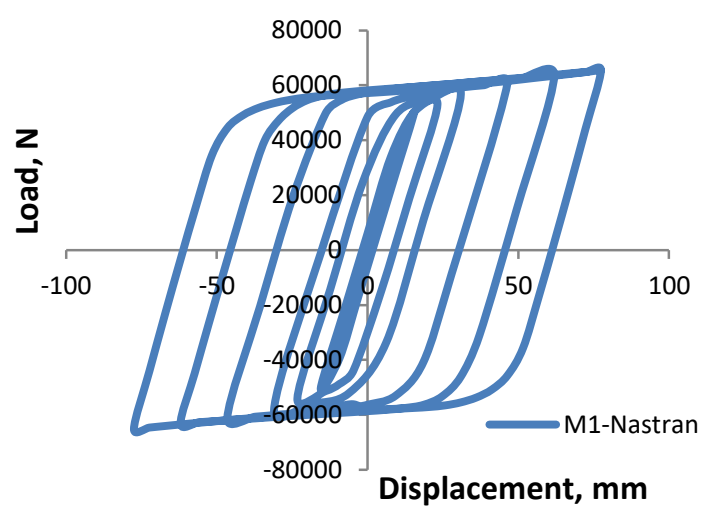

Gambar 12.Kurva beban vs perpindahan terhadap link panjang dengan beban siklik.

\subsection{Pengaruh pengaku diagonal terhadap perilaku link panjang}

Analisa perilaku link panjang dalam studi pendahuluan ini dilakukan terhadap 3 (tiga) jenis benda uji yaitu link panjang tanpa pengaku badan (sesuai ketentuan AISC 2010 untuk link panjang) yang kemudian akan dibandingkan dengan kinerja link dengan pengaku diagonal badan, dan link dengan pengaku cross diagonal pada kedua ujung link dengan jarak 2bf (Gambar 13).

Inovasi berupa pemberian pengaku diagonal pada badan link panjang diharapkan mampu meningkatkan kinerja link dalam hal peningkatan kemampuan link dalam menerima beban maksimum, peningkatan kekakuan maupun kemampuan disipasi energi.Karena belum ada ketentuan yang mengatur mengenai perencanaan link dengan tambahan pengaku diagonal, maka sebagai studi awal dilakukan analisis secara numerik terhadap dua model link dengan pengaku diagonal.

Gambar 13 (a) menunjukkan bahwa dengan pemberian beban statik monotonik dapat meningkatkan kemampuan link dalam menerima beban hingga 16.96\% (Tabel 2) terhadap link panjang dengan pemberian pengaku diagonal badan (Model 2) dan 
pengaku cross diagonal (Model 3) jika dibandingkan dengan link panjang tanpa pengaku badan (Model 1). Peningkatan link dalam mendisipasi energi diperlihatkan pada Gambar 13 (b) yang ditandai dengan terjadinya peningkatan kemampuan link dalam menerima beban serta peningkatan kekakuan akibat penambahan pengaku diagonal pada badan link panjang.Selain itu dengan melihat distribusi tegangan yang terjadi selama pembebanan juga dapat ditinjau kondisi link pada saat terjadi kelelehan awal dan kondisi link pada saat menerima beban berupa perpindahan.

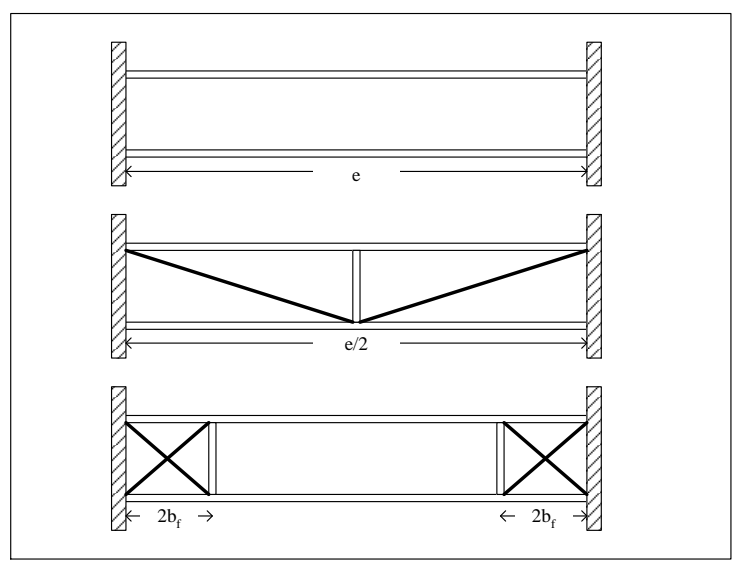

Gambar 13. Tiga model benda uji yang digunakan

Tabel 2.

Peningkatan nilai kekuatan terhadap tiga variasi pengaku diagonal pada link panjang

\begin{tabular}{|c|c|c|}
\hline Model & Load (N) & $\begin{array}{c}\text { Prosentase } \\
\text { Peningkatan }\end{array}$ \\
\hline 1 & 60860.1 & - \\
\hline 2 & & 16.50 \\
\hline (diagonall) & 70904.91 & 16,96 \\
\hline $\begin{array}{c}\text { (Cross } \\
\text { diagonal) }\end{array}$ & & \\
\hline
\end{tabular}

Tabel 3.

Perpindahan Leleh dan Kapasitas Beban saat Leleh Pada Link Dengan Beban Monotonik

\begin{tabular}{|c|c|c|}
\hline Model & $\begin{array}{c}\text { Perpindahan } \\
\text { Leleh }\left(\boldsymbol{\delta}_{\mathbf{y})}\right. \\
(\mathbf{m m})\end{array}$ & $\begin{array}{c}\text { Beban } \\
\text { Leleh }\left(\boldsymbol{\delta}_{\mathbf{y}}\right) \\
(\mathbf{N})\end{array}$ \\
\hline 1 & 15.48 & 50164.58 \\
\hline 2 & 15.44 & 55537.86 \\
\hline $\begin{array}{c}\text { (diagonal) } \\
\text { (cross diagonal }\end{array}$ & 15.5 & 54411.63 \\
\hline
\end{tabular}
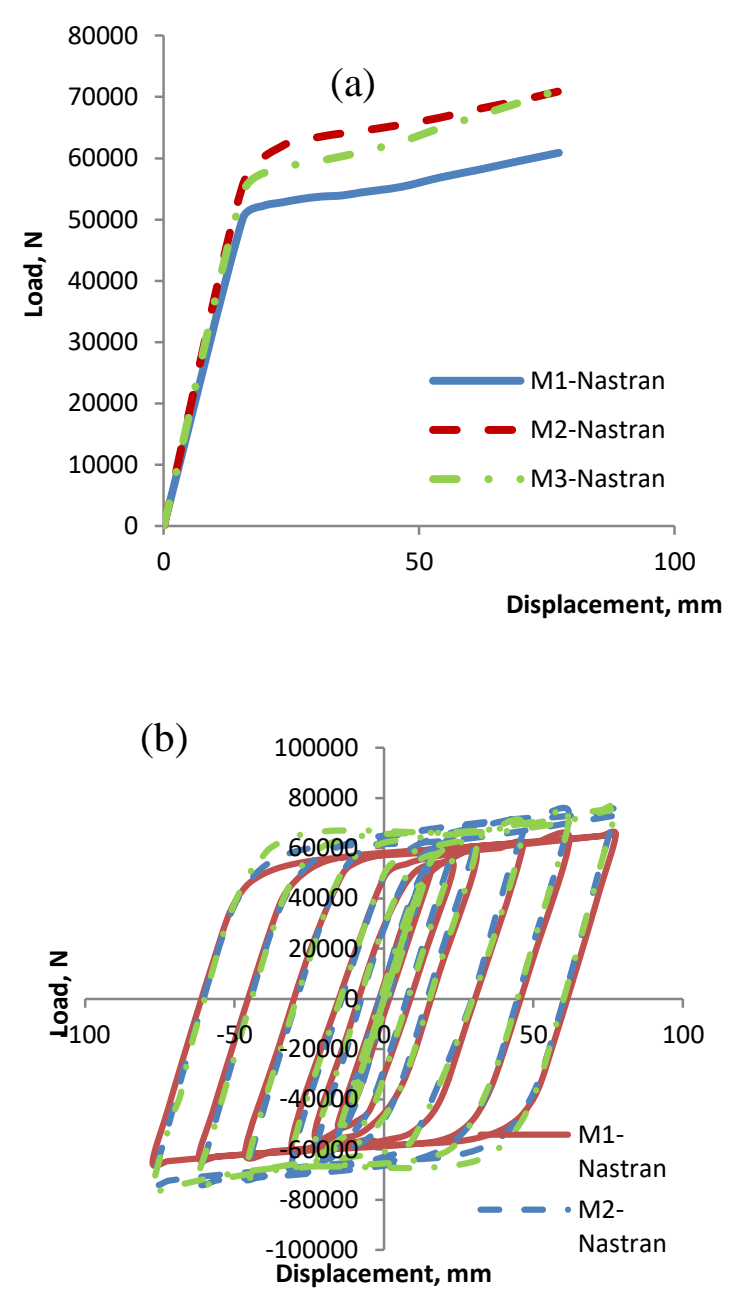

Gambar13.Perbandingan konfigurasi link panjang dengan dan tanpa pengaku diagonal badan terhadap beban vs perpindahan akibat (a). beban monotonik dan (b). beban siklik.

Tabel 3 memperlihatkan bahwa bahwa kelelehan awal terjadi pada saat displacement 
$5.4 \mathrm{~mm}$, namun kemampuan link dalam menerima beban pada saat kelelehan awal bervariasi tergantung pada model link yang dianalisis.

Berdasarkan kurva beban - perpindahan diatas maka diperoleh hasil perbandingan nilai beban maksimum, kekakuan dan enegi disipasi dari setiap model sebagai berikut :

Tabel 4. Beban maksimum tiap siklus pembebanan pada tiga jenis model link

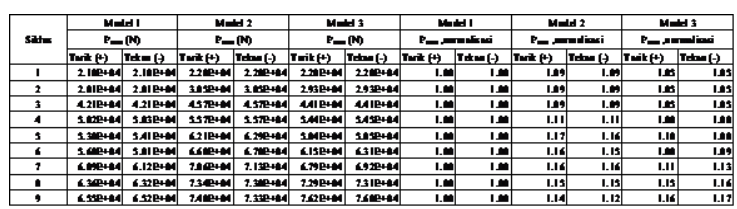

Tabel 5. Kekakuan per siklus pada tiga jenis model link
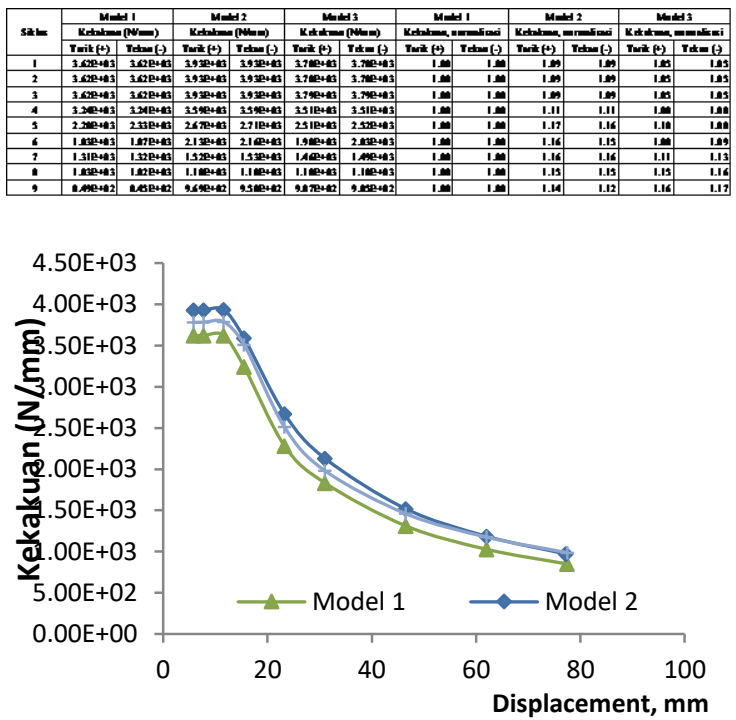

Gambar 14. Perbandingan kekakuan per siklus pada 3 jenis benda uji.

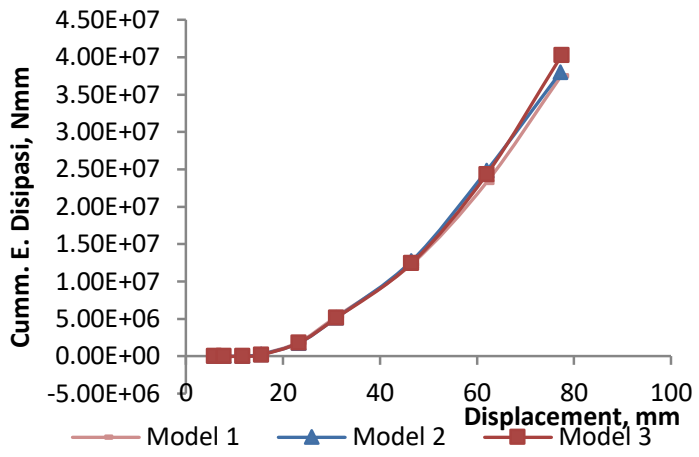

Gambar 15. Perbandingan energi disipasi kumulatif per siklus pada 3 jenis benda uji
Tabel 6. Energi Disipasi

Pada Tiga Jenis Model Link

\begin{tabular}{|c|c|c|c|c|c|c|}
\hline \multirow{2}{*}{ Siktus } & \multicolumn{3}{|c|}{ Knergi Disipas (Nmm) } & \multicolumn{3}{|c|}{ Fnergi_Dispasi ( $\mathrm{Nmm}$ ) } \\
\hline & Model 1 & Model 2 & Model 3 & Model 1 & Model 2 & Model 3 \\
\hline 1 & $4.72 \mathrm{E}+01$ & $5.77 \mathrm{E}+01$ & $530 \mathrm{E}+01$ & 1.00 & 122 & 1.12 \\
\hline 2 & $1.65 \mathrm{E}+02$ & $2.01 E+02$ & $1.85 \mathrm{E}+02$ & 1.00 & 122 & 1.12 \\
\hline 3 & $8.93 \mathrm{E}+02$ & $9.62 \mathrm{E}+02$ & $8.41 \mathrm{E}+02$ & 1.00 & 1.08 & 099 \\
\hline 4 & $2.85 \mathrm{E}+05$ & $253 \mathrm{E}+05$ & $2.09 \mathrm{E}+05$ & 1.00 & 0.89 & 0.73 \\
\hline 5 & $157 \mathrm{E}+06$ & $151 \mathrm{E}+06$ & $158 \mathrm{E}+06$ & 1.00 & 0.96 & 1.01 \\
\hline 6 & 3 3.44E+06 & $3385+06$ & $3335+06$ & 1.00 & 098 & 0.97 \\
\hline 7 & $7.015+06$ & $759 \mathrm{E}+06$ & $730 \mathrm{E}+06$ & 1.00 & 1.08 & 1.04 \\
\hline 8 & $1.10 \mathrm{k}+07$ & $121 \mathrm{E}+07$ & $1.19 E+07$ & 1.00 & 1.10 & 1.08 \\
\hline 9 & $1.43 E+07$ & $131 \mathrm{E}+07$ & $1.60 \mathrm{E}+07$ & 1.00 & 0.92 & 1.12 \\
\hline Tual & $3.75 E+07$ & $3.80 \mathrm{E}+07$ & $4.03 E+07$ & 1.00 & 1.01 & 1.07 \\
\hline
\end{tabular}

Berdasarkan hasil studi awal yang telah dilakukan secara numerik, ditemukan suatu indikasi bahwa pemasangan pengaku diagonal pada bagian badan elemen link panjang profil WF dapat meningkatkan kemampuan link dalam menahan gaya lateral, kekakuan dan meningkatkan kemampuan link dalam diipasi energi per siklus yang diperoleh dari hasil pembebanan kuasi statik (siklik).

\section{KESIMPULAN}

Makalah ini memaparkan studi pendahuluan yang dilakukan secara numerik dengan pendekatan elemen hingga terhadap perilaku link panjang dengan menggunakan pengaku yang dipasang secara diagonal pada bagian badan profil WF. Hasil analisis memperlihatkan bahwa pengaku diagonal mempunyai pengaruh yang cukup signifikan terhadap peningkatan kinerja link panjang.

Makalah yang kami sajikan ini adalah hasil studi awal dan belum mempunyai suatu kesimpulan yang valid. Studi secara eksperimental telah dilakukan di laboratorium Mekanika Struktur PAU-ITB. Dan kami sangat mengharapkan masukan-masukan dari temanteman Peneliti, Praktisi dan Mahasiswa untuk kesempurnaan penelitian ini. 


\section{UCAPAN TERIMA KASIH}

Peneliti mengucapkan terima kasih yang sebesar-besarnya kepada program I-mhere ITB atas Hibah Penelitian Konstribusi Hasil Riset pada Mata Kuliah Terkait Infrastruktur Tahan GempaTahun Anggaran 2010 (Nomor Kontrak : 038/KO1.1/I-MHERE ITB/SPK/2010) yang telah membiayai penelitian ini.

\section{DAFTAR PUSTAKA}

Nidiasari.(2010), Kajian Numerik Perilaku Link Panjang dengan Pengaku Diaonal Badan pada Sistem RAngka Baja Berpengaku Eksentris, Tesis Magister Teknik Sipil, Pengutamaan Rkayasa Struktur, ITB.

Yurisman. (2010), Perilaku Link dengan Pengaku Diagonal Badan pada Sistem Struktur Rangka Baja Berpenopang Eksentrik (EBF), Disertasi Doktoral Teknik Sipil, Pengutamaan Rekayasa Struktur, ITB.

Yurisman, Bambang budiono, Muslinang Moestopo. (2010), Behaviour of Shear link of WF Section with Diagonal Stiffener of Eccentrically Braced Frame (EBF) of Steel Structure, ITB Journal Engineering Science, No.2, 2010, 103128.

Novan, Andre (2008), Peningkatan Kinerja Link Geser dengan Sambungan Baut Tipe Flush yang Memikul Beban Siklik, Tesis Magister Teknik Sipil, Pengutamaan Rekayasa Struktur, ITB.

Guo-Qiang Li, Jin-Jun Li. (2007).

Advanced Analysis and Design of Steel Frames.John Wiley \& Sons Ltd.

AISC (2005), Specification for Structural Steel Building, Chicago, American Institute of Steel Construction.
Richard P.W, Uang C.M.(2005). Effect o Flange Width-Thickness Ratio on Eccentrically Braced Frames Link Cyclic Rotation Capacity, Journal of Structural Engineering, Vol 131, No. 10, Oktober 1.

Becker, Roy, Ishler, Michael (1996), Seismic Design Practice For Eccentrically Braced Frames Based on The 1994 UBC, Steel Tips Journal.

Engelhardt, Michael D., Popov, Egor P.(1992). Experimental Performance of Long Link in Eccentricaly Braced Frames. Journal of Strctural Engineering.Vol. 118, No. 11, November.

Engelhardt, Michael D., Popov, Egor P. (1989) ,Behavior of Long Links in Eccentrically Braced Frames, Earthquake Engineering Research Center UBC/EERC-89/01, College of Engineering University of California at Barkeley.

Engelhardt, Michael D., Popov, Egor P. (1989). On Design of Eccentrically Braced Frames, Earthquake Spectra Vol. 5, No. 3.

Popov, Egor P., Engelhardt, Michael D. (1988). Seismic Eccentrically Braced Frames, Journal Construction Steel Research 10. P.321-354.

\footnotetext{
MSC/NASTRAN, MSC/ NASTRAN Handbook for Non Linear Analysis Version 67.The MacNeal Schwendler Corporation., Los Angeles. Customer ID : HK 52721 NSI Ref. \#171-10,.
} 